\title{
A CONSUMAÇÃO DO GOLPE E O MOVIMENTO ESTUDANTIL BAIANO CONTRA A DITADURA.
}

José Alves Dias ${ }^{1}$

\begin{abstract}
RESUMO
Perplexos diante da concretude do golpe, da impossibilidade de reação do governo João Goulart e da repressão violenta a que foram submetidos, os estudantes brasileiros, sob a direção da União Nacional dos Estudantes (UNE), pouco fizeram nos momentos posteriores à intervenção dos militares. Contudo, após a rearticulação política, houve uma intensa mobilização estudantil e alguns segmentos, particularmente secundaristas e universitários, vários deles militantes ou simpatizantes do Partido Comunista Brasileiro (PCB), e mais tarde das suas dissidências, demonstraram com bastante veemência sua insatisfação contra as imposições arbitrárias da autocracia instituída. Ainda que na Bahia isso não tenha sido uma exceção, a demonstração da intensidade da violência repressiva e a capacidade de mobilização de setores sociais pretende descontruir as interpretações que diferenciam qualitativamente tanto a atuação autoritária quanto a resistência dos atingidos. Desse modo, será possível conceber a ditadura militar brasileira como a expressão mais acabada do projeto de dominação da oligarquia-liberal-burguesa no Brasil que, na direção de um Estado centralizado e modernizante instituído pelo golpe de 1964, tentava impor-se arbitrariamente no poder.
\end{abstract}

Palavras-chave: educação, movimento estudantil, ditadura.

\section{THE CONSOLIDATION OF THE COUP AND THE STUDENT MOVIMENT IN BAHIA AGAINST DICTATORSHIP}

\begin{abstract}
Perplexed by the concreteness of the coup, the impossibility of the government's reaction João Goulart and violent repression they have undergone, Brazilian students, under the direction of the National Union of Students (UNE), did little to further the military intervention moments. However, after the political reorganization, there was an intense student mobilization and some segments, particularly high school and college, many of them militants or sympathizers of the Brazilian Communist Party (PCB), and later their dissent, demonstrated their dissatisfaction with enough vehemence against the impositions arbitrary set of autocracy. While in Bahia this has not been an exception, demonstrating the intensity of repressive violence and the ability to mobilize social sectors aims to deconstruct the interpretations that differ both qualitatively authoritarian action and resistance of those affected. Thus, it is possible to conceive of the Brazilian military dictatorship as the most perfect expression of the design rule of the oligarchy-liberalbourgeois in Brazil toward a centralized and modernizing state established by the 1964 coup, tried to impose itself arbitrarily on the power
\end{abstract}

Keywords: education, student movement, dictatorship. 


\section{INTRODUÇÃO}

Apesar do controle governamental, da repressão veemente e das dissensões internas e externas, o movimento estudantil na Bahia foi ativo contra a ditadura e persistente na reivindicação de seus interesses. Em especial, as manifestações que ocorreram em 1968 resultaram de um longo processo de mobilização e seguiram as mesmas estratégias e proporções dos anos anteriores.

É evidente que a convergência de fatos na esfera internacional, tais como, a greve geral, ocorrida em maio de 1968, na França; a oposição à Guerra do Vietnã, a partir de 1965, nos Estados Unidos e outros pequenos protestos verificados noutras partes do mundo, favoreceu a uma efervescência das ideias libertárias no cenário político nacional. No entanto, "o ano curto de todos os desejos", conforme expressão de Daniel Aarão Reis Filho (1998), não pode ser isolado de um processo de mobilização interna, que vinha se desenvolvendo há vários anos em ritmo mais ou menos idêntico.

Do mesmo modo, a referência focada em determinadas regiões do país, como o Centro-Sul, por exemplo, pode dissimular os fatos históricos e demarcar de maneira equivocada a oposição contra a ditadura e seus efeitos nefastos. A principal razão da concentração geográfica e temporal da análise sobre os fatos políticos que cercam "o ano que não terminou", como descritos por Zuenir Ventura (1988), está na perspectiva de abordagem direcionada especificamente para alguns agentes repressores ou para determinados movimentos organizados de oposição à ditadura.

Neste sentido é muito proveitoso o estudo de Sandra Regina Barbosa da Silva (2013) que comprova a existência de atividades das organizações armadas na Bahia, tais como, o Partido Comunista Brasileiro Revolucionário (PCBR), Movimento Revolucionário Oito de Outubro (MR-8) e a Vanguarda Armada Revolucionária (VAR - Palmares), de forma intensa e efetiva, desconstruindo as interpretações que imputam menor densidade na repressão ou na reação dos opositores à ditadura se confortadas com outras regiões dos pais.

Nesse caso, ainda que por questões metodológicas essas restrições sejam imprescindíveis à apreciação do assunto, a visão global que envolve o autoritarismo estatal, as ações de governo, as estratégias da classe dominante e dos grupos de oposição são necessárias para a fundamentação crítica. Deste modo, e somente com essa finalidade, buscaremos deslocar o eixo de análise para Salvador, a capital baiana, com o intuito de evidenciar a repressão violenta em 1968 e os quadros da militância política de esquerda que se opuseram á ditadura através do confronto direto com o aparelho repressivo. Nossa principal fonte foram os jornais da imprensa baiana que registraram toda a movimentação estudantil dos anos 1960 e destacaram a participação do governo estadual, dos parlamentares municipais e estaduais e da população em geral.

\section{O IMPACTO DO GOLPE SOBRE O MOVIMENTO ESTUDANTIL}

Os estudantes sempre estiveram presentes nas decisões políticas que afetaram profundamente a sociedade brasileira e, não foi diferente, a partir do golpe de 1964. No entanto, segundo Wladimir Palmeira, líder estudantil de projeção nacional, o movimento estudantil pré-64.

Teve muitas qualidades e muitas lideranças, mas era uma força de apoio a um movimento muito mais forte, o movimento operário, sobretudo o operário das estatais, o movimento camponês, muito forte nessa época e o próprio movimento sindical. O movimento de antes de 64 foi, ainda, muito vinculado ao aparelho do Estado [...] dependia muito do apoio institucional, dependia muito, no final, de 
Jango. O movimento [...] tinha na realidade pouca força. (RAPOSO, 1994, p.255).

Os estudantes que militavam em partidos ou organizações antes de 1964, ainda que divergentes entre si, também estiveram vinculados às propostas reformistas do governo e tinham esperança de que a aproximação de João Goulart com os trabalhadores e demais segmentos sociais progressistas trouxesse resultados positivos para a sociedade brasileira.

Por outro lado, no momento em que os civis e os militares golpearam a ordem constitucional brasileira, os universitários e secundaristas tinham, também, uma forte vinculação política com os partidos de esquerda. O Partido Comunista Brasileiro, na ilegalidade, era a principal força de inspiração marxista, porém, não a única. As dissidências, ocorridas muito antes do golpe, fizeram com que muitos militantes rompessem com o PCB tendo em vista a sua insatisfação com a linha política do partidão. Sobre isso, o historiador Daniel Aarão Reis destacou:

\footnotetext{
As bases estudantis, envolvidas nos primeiros movimentos sociais, ganhavam autonomia. Fugiam ao controle das instâncias formais, estabeleciam relações entre si, inclusive no plano interestadual mantinham contatos e recebiam influências da POLOP e do PC do B. (REIS F. ${ }^{\circ}, 1985$, p.48)
}

Desde sua criação, em 11 de agosto de 1937, pouco antes do golpe que originou o Estado Novo, a União Nacional dos Estudantes acumulou uma larga experiência de militância política sob a hegemonia de lideranças socialistas e comunistas, exceto por um breve interregno, em meados da década de cinquenta, quando esteve sob a direção dos grupos de direita ligados à União Democrática Nacional (UDN).

Em 1961, com a criação do Centro Popular de Cultura (CPC), a UNE levou para o todo o país o teatro e o cinema populares e ampliou a discussão sobre a reforma universitária. Na mesma época, sob a presidência do baiano Oliveiros Guanais, cresceu o predomínio da Ação Popular (AP) no movimento estudantil e tomou vulto as campanhas nacionalistas em defesa das empresas brasileiras e do ensino público e gratuito. Junto com a UNE surgiram outros movimentos de cultura e educação popular que "buscava caminhos alternativos às propostas tradicionais e conservadoras" (CUNHA \& GÓES, 1994, p.30).

Dentre as várias composições a Organização Revolucionária Marxista (ORM) também conhecida como POLOP, dissidência do PCB desde 1961, tinha entre seus militantes estudantes universitários. Do mesmo modo, as discordâncias de João Amazonas, Maurício Grabois e Pedro Pomar, cindiram os comunistas brasileiros em 1962, formando a sigla PC do B. Também o Partido Operário Revolucionário - Trotskista (PORT), desde 1953, reunia estudantes e intelectuais em torno da tese da revolução permanente. Muito forte no movimento estudantil era a presença da AP, uma organização originada no seio da Juventude Universitária Católica (JUC) com forte tendência humanista e socialista, que posteriormente tornou-se uma organização eminentemente marxista.

Assim, quando o golpe militar rompeu a vinculação institucional dos movimentos estudantil e sindical com o governo João Goulart, a entidade vivia um momento especial. Todavia, por conta das vinculações institucionais com Jango e da militância política na esquerda, as lideranças estudantis foram imediatamente presas após o golpe e a sede da UNE, no Rio de Janeiro, invadida e incendiada por integrantes do Comando de Caça aos Comunistas (CCC). O impacto dessa repressão ao movimento estudantil é assim definido por Zuenir Ventura (1988):

Quando os militares deram o golpe em abril de 64, abortaram uma geração cheia de promessas e esperanças. A esquerda, como acreditava Luís Carlos Prestes então, não estava no governo, mas já estava no poder. (VENTURA, 1988, p. 44) 
Alfredo Sirkis (1988, p. 58), líder estudantil e membro de Vanguarda Popular Revolucionária (VPR) nos anos 1960, que contava na época com trezes anos, desabafou: "Acompanhei pelo rádio a progressão das tropas de Minas Gerais que depuseram o governo de Jango. Meus olhos enchiam-se de lágrimas ao som das marchas e dos dobrados militares".

Daniel Aarão Reis, não exagera quando afirma que o golpe de 1964 destruiu partidos, carreiras políticas, sonhos e vidas. Conquanto isso seja absolutamente verdadeiro, muitos estudantes, apesar de todas as perseguições permaneceram ativos politicamente, realizando congressos clandestinos e passeatas de protesto, mesmo após a extinção legal da UNE, em 1965.

\section{4: O ANO FERVILHANTE}

Já vinham de longe os rumores de uma desestabilização política do governo Jango e da movimentação nos quartéis, por isso, a sociedade baiana já experimentava, há algum tempo, o mesmo clima de tensão vivido em todo o país. Nesse contexto, um fato pitoresco e de larga repercussão, entretanto, revelou burguesia baiana a rebeldia daquela juventude, embaraçando aqueles que titubeavam entre os legalistas e os golpistas.

Como de praxe, ocorreu no início do ano letivo de 1964 a aula inaugural da Universidade Federal da Bahia, com a presença do governador Lomanto Júnior, de outras autoridades civis, eclesiásticas e militares. No início do discurso solene do orador Clemente Mariani, banqueiro de família tradicional e conservadora, os estudantes presentes no plenário irromperam em vaias. Depois de alguns instantes de convulsão generalizada no auditório da Reitoria, a situação foi controlada com a interferência do governador. Contudo, a assembleia foi dissolvida, e os presentes dispersados completamente atônitos com tamanha ousadia. Na manhã seguinte, todos os jornais da capital traziam notícias do fato que se tornou assunto predominante na Assembleia Legislativa e Câmara Municipal.

O reitor convocou uma reunião do Conselho Universitário que se realizou sob a proteção da polícia, uma vez que dezenas de estudantes concentraram-se no jardim da Reitoria, em solidariedade aos colegas. Alguns meses depois, em atendimento a uma circular do Ministro da Educação, Flávio Suplicy de Lacerda, o Conselho instituiu comissão para apurar e punir os responsáveis pelas manifestações na Reitoria. Essa foi a primeira, das muitas manifestações contra as oligarquia-liberal-burguesa na Bahia, artífices e colaboradores da ditadura.

Com a consumação do golpe e a efetivação dos planos conspiratórios contra o presidente da República, os militantes políticos de esquerda se mobilizaram para resistir. No estado da Guanabara e em São Paulo muitos bancários, metalúrgicos, têxteis, portuários e petroleiros sustentaram, por algum tempo, a expectativa de uma mobilização popular contra o ato ilegal e declararam greve geral em apoio ao presidente e ao governo constitucional.

Por analogia, muitos líderes políticos, estudantis e sindicais baianos tentaram enfrentar as forças repressivas na capital, contudo, diante da situação irreversível, fugiram para Feira de Santana, conforme depoimento do ex-prefeito da cidade, Francisco Pinto:

A cidade de Salvador encontrava-se cercada pelas tropas e centenas de prisões foram efetuadas. Vários líderes operários e estudantis que escapavam se deslocaram para o nosso município. Discutimos o que fazer e resolvemos resistir. Uma série de providências foi adotada para enfrentar os golpistas. Não cabe aqui enumerá-las. A ausência de reação no resto do país nos levou à desmobilização. Providenciamos a fuga para a maioria dessas lideranças. (NADER, 1998, p. 1489) 
As providências não reveladas por Chico Pinto consistiram em convocar a guarda municipal, fazer comícios, armar barricadas, na tentativa de transformar a cidade no centro da resistência, de onde sairiam para libertar a capital. No interior, as notícias alvissareiras causavam enorme expectativa na população, que organizou muitas manifestações de apoio ao Governo João Goulart, acompanhadas de perto por grupos conservadores que, pressurosos, iriam delatar todos os manifestantes na primeira oportunidade.

Logo, as tropas do exército estavam em praticamente todos os municípios baianos efetuando prisões e praticando todo tipo de arbitrariedades contra os aliados do presidente deposto pelo golpe militar. Desta forma, as primeiras tentativas de reação à intervenção militar malograram diante da tensão imposta pela violência generalizada e da desarticulação das forças políticas contrárias ao golpe. ${ }^{2}$

Entretanto, a "revolução faltou ao encontro", conforme expressão consagrada do historiador Daniel Aarão Reis Filho (1990) e as minorias mobilizadas para resistir foram presas, torturadas e processadas ilegalmente. As escassas manifestações de resistência foram imediatamente reprimidas, as autoridades civis e os comandantes de tropas aliadas ao presidente deposto, como em Pernambuco e Rio Grande do Sul, foram presos e destituídos. O presidente João Goulart, de quem os aliados esperavam alguma reação, tentou articulações em Brasília e, posteriormente em Porto Alegre, decidindo finalmente pelo exílio.

As propostas reformistas haviam caído com João Goulart, do mesmo modo que sucumbiram as alianças entre os sindicatos e o poder populista. As principais lideranças estaduais do PCB, AP e POLOP estavam presas ou escondidas. Todos os simpatizantes ou aliados do governo de Jango foram presos sob a alegação de que durante aquela administração. Com a desarticulação dos setores políticos que apoiavam o regime democrático formalmente estabelecido através do processo eleitoral, a resistência oposicionista na Bahia restringiu-se apenas ao plano teórico, infausto, pela manifesta impossibilidade de execução.

\section{CONSOLIDAÇÃO DA DITADURA}

A conspiração contra o governo João Goulart vinha sendo desenvolvida desde a renúncia de Jânio Quadros, em 1961, mobilizada pelo temor dos setores conservadores das Forças Armadas e da política brasileira de que o presidente entregasse o poder aos comunistas. Segundo a interpretação dos comandantes militares,

\footnotetext{
Durante o governo de João Goulart esteve instalado no Brasil um movimento geral de subversão e corrupção, inclusive da própria cúpula administrativa, que tinha por objetivo desmoralizar o regime democrático existente no país. O solapamento das instituições adrendemente (sic) preparado por profissionais agitadores conduziu todos à descrença. À guisa de defender o país de grupos econômicos, pregavam contra o regime, exaltando as qualidades de sistemas de governo que atentam contra a ordem político-social estabelecida na nossa constituição. Pregava-se o crime contra as instituições abertamente. Nesse caso, era indispensável a sua segregação do meio social, por suas atividades antidemocráticas. (ARQ. DA 6. ${ }^{\mathrm{a}}$ RM. AUTOS DO IPM, FLS. 301 A 310)
}

Em virtude disso, a "assepsia social" realizada para afastar e estigmatizar quaisquer pessoas vinculadas ao governo deposto foi violenta. Mesmo assim, logo após o golpe, os militantes de esquerda se prepararam para recompor seus quadros e voltar à militância contra o regime de quartel. Como no resto do país, os estudantes baianos, secundaristas e universitários, foram mais ágeis na reestruturação de suas bases políticas e na substituição 
de suas lideranças, motivo pelo qual se tornaram a vanguarda dos movimentos progressistas populares contra a ditadura.

Pouco tempo depois, ainda que o cerco se apertasse e os ditadores estivessem cada vez mais afeiçoados ao poder, começaram a organizar assembleias, atos e passeatas para exigir reformas no ensino, ampla liberdade de expressão, democracia de fato e anistia política para seus companheiros. A eles se uniram alguns profissionais liberais, políticos, operários, professores, intelectuais, estivadores, petroleiros e trabalhadores rurais, buscando alternativas para romper o cerco repressivo e mobilizar o povo na luta contra a ditadura, mesclando reivindicações de classe e categoria com demandas políticas que resultaram num amplo conjunto de ações com efeitos distintos. Substancialmente foram os estudantes provenientes, em sua maioria, das classes médias que, proferindo palavras de ordem, ocuparam as ruas de Salvador para protestar contra a tirania das classes dominantes.

Entretanto, a movimentação na $6^{\mathrm{a}}$ Região Militar, sob o comando do general de Brigada Manoel Mendes Pereira, empossado pouco antes do golpe, deixou claro o apoio majoritário dos grandes grupos econômicos e políticos. Logo, começaram a se manifestar os aliados de primeira e de última hora, aderentes ao poder e empenhados em obter dele vantagens e privilégios.

Alguns deputados apresentaram moção nos seguintes termos:

\begin{abstract}
A Assembleia Legislativa do Estado, fiel aos sentimentos democráticos do povo baiano, expressa sua solidariedade às forças democráticas, civis e militares, que, obedientes às lideranças dos governadores Magalhães Pinto e Adhemar de Barros, Carlos Lacerda, Ney Braga, Mauro Borges e Hugo Meneguetti e os generais Amaury Cruel, Mourão Filho, Humberto Castelo Branco, Justino Alves e outros ilustres militares, que estão para restaurar no Brasil a legalidade democrática vítima da traição de um governo que se acumpliciava com os piores inimigos da liberdade, os comunistas. (A TARDE, 02/04/1964, p. 02)
\end{abstract}

No plenário do legislativo municipal, o vereador Paulo de Magalhães Dantas apresentou outra moção de aplauso às forças armadas que ascenderam ao poder através do movimento militar que destituiu o presidente eleito João Goulart. Em quase todos os municípios do interior, a situação se repetiu, e políticos eleitos pelo voto direto da população nas eleições de 1962, por simpatia ou receio das listas de cassações, que logo viriam, aplaudiram os civis e militares golpistas. Claro está que muitas das casas legislativas do Estado foram ocupadas por soldados do exército e da polícia militar em votações de matéria dessa natureza, redundando em intimidação e violência contra os parlamentares.

Mesmo entre os estudantes havia apoio aos militares. Algumas entidades estudantis como o Movimento Universitário Democrático (MUD), a Associação Soteropolitana de Estudantes Secundaristas (ASES) e o Movimento Estudantil Patriótico (MEP) firmaram nota pública contra a infiltração das ideias comunistas no movimento estudantil da Bahia e convocaram os voluntários para apoiar as Forças Armadas. (A TARDE, 03 e 06/04/1964, p. 03 e 07).

No extremo oposto estavam entidades estudantis, artísticas e sindicais que se opunham ferrenhamente ao golpe e algumas delas, como o Sindicato dos Petroleiros (SINDIPETRO), tiveram suas sedes ocupadas por soldados designados pelo comando da $6^{\mathrm{a}}$ Região Militar e pela Polícia Militar. ${ }^{3}$

No caso citado foi apreendido farto material considerado de "natureza subversiva" que foi destinado à Vila Militar do Bonfim. Três meses depois, o material apreendido foi 
mostrado numa exposição pública com a exibição paralela de filmes que faziam propaganda do regime militar e criticavam as atividades "subversivas".

Nem todas as lideranças políticas baianas se alinharam aos militares naquele momento. Foram muitos os perseguidos por seus adversários políticos porque tinham um referencial reformista ou mesmo progressista e não admitiam que a democracia formal fosse solapada repentinamente como aconteceu. Nesse processo repressivo aos opositores do golpe a cassação do prefeito de Feira de Santana, Francisco Pinto dos Santos é bastante exemplar. O coronel Luís Artur de Carvalho, designado pelo exército para comprovar as denúncias, optou por aconselhar aos vereadores que faziam oposição ao executivo municipal a manter Chico Pinto no cargo. Somente após muita pressão junto a Castelo Branco, o prefeito foi deposto e preso. Segundo ele, as denúncias feitas pela oposição passaram a ser confirmadas pela população torturada pelas tropas do Exército sob o comando do major Hélvio Moreira que

chegaram em Feira e se alojaram em um armazém de fumo. Me prenderam. Naquele armazém, as torturas foram monstruosas. Dezenas de pessoas, uma de cada vez, eram arrochadas em uma prensa para enfardar fumo, sob ameaça de nela continuarem se não confessassem que o prefeito era comunista. (SANTOS, 1998, p. 149)

Aliás, a tortura, ferramenta sistemática de investigação nas fases de instauração dos Inquéritos Policiais Militares (IPM's), foi largamente utilizada em toda a Bahia desde as primeiras prisões realizadas logo após o golpe civil-militar. Em setembro do mesmo ano, petroleiros, portuários e estudantes presos denunciaram ao general Ernesto Geisel, chefe da Casa Militar da Presidência da República, em visita a Salvador, as condições de insalubridade, a desinformação sobre os processos, as privações das famílias e a violência contra os prisioneiros políticos na Bahia. Depois de vistoriar as celas e conversar com os presos, que dormiam no chão de celas úmidas, o militar considerou que a situação deles era "satisfatória". Concomitante a sevícias e torturas, os opositores ao regime militar na Bahia foram punidos, também, com a aplicação do Ato Institucional $\mathrm{n}^{\circ} 01$ que solapou repentinamente direitos elementares do cidadão brasileiro.

\section{COMEÇA A REARTICULAÇÃO ESTUDANTIL}

A juventude brasileira, na década de sessenta, conheceu, na sua experiência cotidiana, os problemas estruturais do sistema de ensino que extrapolavam o aspecto formal e interno das instituições de ensino superior, ou seja, além de todas as dificuldades encontradas para ingressar e permanecer na universidade sentia-se despreparada profissionalmente, tendo em vista as deficiências na qualidade do ensino. Tal situação atingia não somente os estudantes das universidades públicas e privadas, mas também, os secundaristas que reclamavam das mesmas falhas no ensino de nível médio e do modo como elas limitavam o acesso à universidade (WEIS, 1969, p. 24-39).

Por outro lado, as verbas militares sobrepunham consideravelmente o orçamento para a educação, e as diretrizes de ensino apontavam para uma formação mecanicista do profissional que atendesse apenas à demanda do mercado e o projeto de desenvolvimento e modernização das classes abastadas. ${ }^{4}$

Diante do quadro apresentado, o sistema educacional brasileira tinha sinais claros de esgotamento e, com tantos problemas, era natural que quisessem ter a liberdade de se organizar e manifestar sua insatisfação, contudo, com a ascensão dos militares, foram proibidos e tiveram a autonomia de suas entidades representativa violentada e novos atos de agressão à liberdade de expressão eram constantemente editados. 
No primeiro ano de vigência do regime autoritário terminou com a decretação da Lei Suplicy que atingia diretamente os estudantes baianos e previa a transformação dos antigos centros em diretórios acadêmicos subordinados à direção das faculdades, obrigava a realização de novas eleições e tornava obrigatório o voto dos estudantes, sob pena de "não poderem se submeter a exame parcial ou final, imediatamente subsequente à eleição". 5

Em vista disso, as lideranças estudantis universitárias começaram o ano de 1965 reagindo à imposição autoritária da referida legislação e recomendaram o voto nulo. Era uma recomendação pouco eficaz numa conjuntura em que faltavam vagas para os cursos superiores na Universidade Federal da Bahia e, por isso mesmo, não houve um elevado número de abstenções. Uma exceção ocorreu na Faculdade de Filosofia, uma vez que, do total de setecentos e dezoito votos válidos, quinhentos e setenta e nove foram nulos. (A TARDE, 23/08/1965, p. 11)

As eleições, contudo, foram bastante tumultuadas gerando conflitos entre os estudantes e Polícia Militar que invadiu as faculdades agredindo estudantes que se manifestavam contra "a lei e as forças discricionárias que a impuseram", segundo suas próprias palavras. (A TARDE, 23/08/1965, p. 07)

Dilapidados dos mais elementares direitos, os estudantes compreenderam a necessidade de se rebelarem contra o sistema de governo que empreendia uma política social tão impiedosa. Em outubro de 1965, pouco antes da decretação do Ato Institucional $\mathrm{n}^{\mathrm{o}}$ 02, que extinguiu o pluripartidarismo, ampliou o poder do executivo e dos tribunais militares para, inclusive, decretar Estado de Sítio, demitir funcionários públicos de todas as esferas, governar por decreto e fechar o congresso, os estudantes em Salvador fizeram uma paralisação de quarenta e oito horas em solidariedade aos seus colegas da Universidade de Brasília, cuja instituição havia sido fechada.

Essa análise conjuntural era o retrato da Bahia, todavia, não se refletia em uma ampla mobilização social. A militância estudantil, apesar das causas justificáveis e da crise que atingia toda a população, não conseguiu mobilizar, exceto em momentos pontuais, o interesse dos baianos para sua causa. A violência contra eles será o único sinal de alerta para a sociedade baiana.

\section{OS SECUNDARISTAS TOMAM A OFENSIVA}

Um fato particular, entretanto, desencadearia um processo de agitação e descontentamento na Bahia que nem mesmo os mais otimistas líderes estudantis ousariam prever. Em meados de 1966, a peça teatral "aventuras e desventuras de um estudante", de Carlos Sarno, aparentemente sem nenhuma relevância política, teve sua encenação proibida pelo diretor do Colégio da Bahia. Segundo o próprio autor, que posteriormente foi excluído do ensino público da Bahia, a peça em linguagem de cordel discutia a realidade do estudante e foi proibida pelo diretor do colégio por "não ter uma linguagem adequada ao ambiente educacional". (INFORMAÇÃO VERBAL). ${ }^{6}$

$\mathrm{O}$ incidente motivou uma greve na tradicional escola secundarista, popularmente conhecida como Colégio Central, e uma grande passeata contra o veto do diretor. Os portões amanheceram guardados pela polícia, diante de uma suposta ameaça de depredação por parte dos estudantes. O diretor afirmou que, dos 5.400 estudantes, apenas 100 ou 150 aderiram à greve, mas a dimensão dos fatos mostra que os números foram bem superiores. Ainda assim, uma portaria da direção constituiu uma comissão composta pelos professores Raul Sá, seu presidente, Nilton José de Souza Ferreira e Walter Matos para apurar o caso, 
que, considerando os argumentos do diretor Walter Reuter, suspendeu os alunos subversivos.

Diante da proibição, os estudantes tentaram exibir a peça na residência dos universitários, no entanto cem policiais interditaram um trecho da Avenida Sete, invadiram o recinto com armas em punho, espancaram, com cassetetes, dezenas de estudantes que vaiavam, perseguindo-os com muita violência até as residências próximas onde foram encontrar refúgio.

Nesse momento os militares ainda não conheciam profundamente seus opositores e ainda estavam sendo instruídos para praticar técnicas refinadas de tortura e, por isso, praticavam uma violenta e generalizada varredura em todos os suspeitos de "subversão". O instrumento mais utilizado naquela conjuntura era a delação que servia como prova cabal do envolvimento com os comunistas.

Apesar disso, o episódio da residência universitária agregou os estudantes secundaristas e universitários de outros estabelecimentos oficiais de ensino que se solidarizaram com os colegas do Central e mantiveram-se em assembleia permanente, até que a Reitoria permitisse a encenação da peça na Residência Universitária, o que não ocorreu. $\mathrm{O}$ assunto tomou uma dimensão social e política de proporções gigantescas e acabou "desencadeando um movimento que mexeu com a cidade inteira, um movimento extremamente bem organizado, um negócio surpreendente [...] foi um movimento que tomou conta da cidade". (INFORMAÇÃO VERBAL) ${ }^{7}$

A iniciativa do governador do Estado, Lomanto Júnior, de convidar uma comissão de estudantes do Colégio da Bahia para ouvir suas reivindicações no palácio sediado na Praça Municipal transformou-se, na verdade, em uma armadilha para prender os membros da comissão, que representava os estudantes do Central, relatou Sarno que compunha a delegação, mas escapou do cerco.

O clima de desconfiança e medo era latente entre os estudantes e a proibição do diretor do Colégio Central, sob alegação de que era ofensiva ao colégio e aos professores levou o ensaio da peça ao Mosteiro de São Bento. D. Timóteo Anastácio, abade do Mosteiro de São Bento, considerou a peça "sem nenhuma intenção político-partidária" e os alunos "puros de espírito". Ao Jornal da Bahia, ele declarou que só podia "aplaudir os esforços despendidos pelos jovens pela cultura e pela liberdade de criação artística e que não via no movimento nenhuma intenção político-partidária, mas um entusiástico e juvenil empenho de criar beleza". (JORNAL DA BAHIA, 02/06/1966, p. 06).

Aliás, o abade de São Bento, contrariando a tendência geral de conservadorismo da cúpula da Igreja na Bahia comandada pelo Cardeal da Silva, "era uma figura muito tolerante, que nos deu acolhida, nos defendeu, defendeu a liberdade das atividades estudantis e culturais, a liberdade de pensamento e construiu um teatro pra gente". (INFORMAÇÃO VERBAL) ${ }^{8}$

A chegada do monge beneditino à Bahia, segundo o Prof. Joviniano Carvalho Neto (1996, p. 24), coincide com o início do regime autoritário militar, e sua ação a partir de então se caracteriza pela "defesa dos direitos humanos violados pelo regime militar e pela abertura, inclusive física, do mosteiro aos opositores políticos e populares do regime e outras categorias marginalizadas da Bahia”. Para ele, a posição do São Bento como ponto de acolhimento e apoio na luta contra a ditadura ficou indelevelmente definida na História da Bahia.

Essas manifestações ocorreram naquele ano com uma frequência assustadora gerando uma série de incidentes de enorme repercussão como o que ocorreu no dia 04 de junho de 1966 durante manifestações estudantis em frente à Reitoria, quando o tenente- 
coronel João Mansur de Carvalho foi atingido por uma pedrada dos estudantes, ao transitar pelo local em companhia do ministro das relações exteriores, Juracy Magalhães. ${ }^{9}$

Segundo narrativa do próprio oficial, havia um grande engarrafamento e um comício de estudantes portando faixas contendo dizeres contra o regime. Um dos estudantes notou o carro que seria do filho do ministro, chamou a atenção de todos e, ao sair do carro, o ministro foi vaiado, enquanto a gritaria abafava seus protestos contra o ato. De punhos cerrados, Juraci dava "vivas" ao presidente Castelo Branco e ao regime. Os estudantes muniram-se de pedras e atiraram em direção ao tenente-coronel, amassando o carro e ferindo-o. A pedrada certeira causou-lhe um hematoma do lado esquerdo do rosto que o levou a submeter-se a uma cirurgia plástica durante três horas para corrigir fraturas das paredes do maxilar superior, do soalho da órbita e afundamento do malar. (A TARDE, 09/07/1966, p. 10)

O clima de insatisfação era contagiante e motivado não somente pelas arbitrariedades do regime, como também, pela falta de espaço físico nas faculdades e o atrelamento de diretores de colégios, professores e membros da administração central das universidades aos golpistas. Foi a conjunção de todos esses fatores que unificou as lutas estudantis na Bahia, nos primeiros anos da década de 1960.

\section{UNINDO FORÇAS CONTRA A LEI ORGÂNICA DO ENSINO}

A ditadura sabia que as notícias dos crescentes protestos redundariam no esfacelamento da imagem construída pelo governo militar. A estratégia era manter a todo custo a aparência de uma democracia constituída a partir de um processo revolucionário que extinguira a corrupção e a ameaça do comunismo. A censura aos meios de comunicação foi, então, uma estratégia eficiente para não editar, adulterar ou mesmo coibir as informações sobre a crise econômica e institucional e os desmandos governamentais. No final de 1966, foi aprovada a Lei de Imprensa, instrumento de manipulação e censura á liberdade de informação.

Em vista disso, os alunos de jornalismo da Faculdade de Filosofia e Ciências Humanas lançaram um manifesto solidarizando-se com os profissionais em greve, o vereador Luís Leal apresentou na Câmara Municipal, no início de 1967, uma moção de apoio ao sindicato dos jornalistas profissionais da Bahia, e estes fizeram gestões para suspensão da votação do projeto da "lei rolha" como ficou conhecida a Lei de Imprensa que foi alvo de críticas de jornalistas brasileiros e estrangeiros.

Vale ressaltar que apesar do apoio discreto dos demais membros da sociedade aos estudantes a crise afetava diretamente a todos os demais segmentos, em especial, os trabalhadores, que sentiam profundamente os reflexos da política econômica. O exemplo mais gritante na Bahia foi percebido nesse mesmo ano quando os soldados do corpo de bombeiros de Salvador, aquartelados, mobilizaram-se para reivindicar reajuste salarial equiparável à Polícia Militar e ameaçaram trazer suas famílias para o quartel se, em 48 horas, a situação não fosse resolvida. O prefeito da cidade, Antônio Carlos Magalhães, ameaçou intervir com a Polícia Militar e o Exército quando esteve com os soldados e, junto com o comandante, ameaçou incluir os manifestantes na Lei de Segurança Nacional.

O prefeito de Salvador, indicado pelos militares, durante a visita ao quartel afirmou que não se intimidava com o estado emocional criado pelos noticiários da imprensa baiana. O coronel Hamilton Drummond acusou o ato de subversão. Os bombeiros, porém, negaram que estivessem em greve e defenderam-se da acusação, afirmando que estavam tão-somente lutando contra a miséria e a fome, pois muitos colegas recorriam ao lixo do rancho à procura de sobras de alimentos para seus filhos. Ganhavam salário inferior ao 
mínimo, o que contrariava a constituição federal. Confirmaram que não deixariam de atender aos pedidos de socorro da população a quem pediam roupa e comida.

Após muita pressão, inclusive das companheiras dos soldados, o prefeito prometeu melhorias e concedeu uma gratificação por risco de vida, mas não aceitou aumentar os salários.

Os estudantes, contudo, não se intimidavam e continuaram propagando seus congressos e exigindo liberdade e promovendo manifestações apesar da repressão e da queda de muitos líderes importantes. Todavia, poucas vezes os baianos viram tamanha manifestação de civismo e cidadania demonstrada em atos concretos de rebeldia, como no momento em que, deixando as salas de aula e partindo para as ruas do centro da cidade, "centenas de estudantes procedentes dos colégios oficiais encheram a Praça Castro Alves com o alarido de seus protestos contra a lei que consideram iníqua". (A TARDE, 22/08/67, P. 03)

Assim, o jornal vespertino definiu textualmente a manifestação discente contra a Lei Orgânica do Ensino que, praticamente, extinguia o ensino público na Bahia. Os artigos 09 e 36 dessa lei permitiam às fundações, que seriam criadas para substituir as escolas públicas, cobrar taxas e mensalidades, reservando ensino gratuito apenas para o nível primário e aos estudantes que provassem insuficiência de recursos.

Os estudantes dos Colégios Isaías Alves, Colégio da Bahia (Central), Severino Vieira, Teixeira de Freitas e Pinto de Carvalho procuraram deputados, lançaram manifestos e fizeram protestos contra a Lei do Ensino em apreciação na Assembleia Legislativa. Receberam irrestrito apoio dos estudantes da Faculdade de Filosofia, da Escola de Teatro e de outras faculdades da UFBA e da Universidade Católica que se manifestaram com faixas e cartazes pelas ruas da cidade. Alguns segmentos da sociedade local se mobilizaram, como em raras vezes durante a ditadura, para apoiar a causa dos estudantes.

Com a aglomeração nas proximidades da Assembleia Legislativa, o presidente da casa acionou a polícia militar que, fortemente armada com baionetas e fuzis, investiu contra um grupo de alunos e professores. No plenário, o deputado Wilson Lins afirmou que

\footnotetext{
Quem combate esse artigo deve é combater a Constituição Federal e do Estado e não a Lei Orgânica, que nada podia fazer a não ser incluí-lo. O resto era demagogia barata e agitação provocada por elementos subversivos que estão explorando estudantes. (A TARDE, 23/08/1967, p. 03)
}

A polêmica sobre essa legislação era muito grande e esteve em discussão por vários dias na Assembleia Legislativa do Estado. Atentos aos fatos, os estudantes prosseguiram, durante cinco dias fazendo passeatas e realizado atos de protesto. Foram atacados com jatos d'água, bombas de gás e golpes violentos. O deputado Wilson Lins acusou os professores do Severino Vieira de insuflar os estudantes, mas estes receberam apoio de intelectuais e artistas baianos.

Cumprindo o destino autoritário que, quase sempre, caracterizou as decisões do poder político na Bahia, a Assembleia Legislativa aprovou, de madrugada, a Lei do Ensino, em terceira discussão, pela maioria da ARENA, após várias sessões realizadas sucessivamente, dada a urgência com que foi tratado o assunto pelos deputados que alegavam cumprir as constituições nacional e estadual que previam o mesmo destino para o ensino gratuito.

A indignação dos estudantes com a aprovação da lei foi tão grande que, apesar de vencidos, continuaram suas manifestações no dia seguinte a partir de uma concentração na Praça da Sé. Uma massa de estudantes agitados quebrou janelas, cercou carros de deputados, danificou carros oficiais com murros, pedradas, garrafadas e pontapés. $\mathrm{O}$ protesto atraiu populares que se juntavam aos estudantes nas vaias à polícia. A repressão 
aos manifestantes ficou a cargo das tropas chefiadas pelo Major Oto Aguiar que os dispersou com duas bombas de gás lacrimogêneo. À noite, novamente, saíram às ruas e apedrejaram, segundo a imprensa, a sede do Jornal da Bahia, o Relógio de São Pedro e a Biblioteca Pública. Dezenas de estudantes foram presos e outro grande número continuou escondido na Faculdade Católica de Direito sob severa vigilância da Polícia.

Essa foi uma das participações mais efetivas, amplas e homogêneas dos estudantes baianos contra as imposições legais da ditadura. Caracterizou-se, também, pela subordinação das instituições locais aos interesses golpistas e de forma inegável o excesso de violência contra os manifestantes causou a antipatia generalizada da população aos militares.

Tamanha pressão popular levou o governador Luís Viana Filho a fazer um pronunciamento oficial na televisão, qualificando o "caso" como um equívoco, sustentando a tese do secretário de que os colégios públicos continuavam gratuitos, embora as fundações pudessem explorar o ensino, cobrar mensalidades e exigir o atestado de pobreza.

\section{REBELDIA NAS RUAS E VIOLENTA REPRESSÃO}

Integrados com o movimento nacional que surpreendia todo o país pelas suas proporções, os estudantes baianos, portando faixas com as palavras de ordem: "polícia mata estudante" e "verbas para as armas, morte para o povo", fizeram passeatas no final de março 1968 para se manifestarem contra a morte do estudante Edson Luís, no restaurante Calabouço, Rio de Janeiro. O assassinato de um líder estudantil, ainda que sem maior notoriedade, iria ter uma repercussão negativa para os militares e mobilizar milhares de estudantes no Brasil inteiro. Com a bandeira nacional hasteada e portando uma faixa negra, o ritual de protesto dos baianos seguiu desde a Praça Castro Alves até a Praça da Sé, continuou pelo Pelourinho e desceu a Barroquinha onde falaram ao povo do luto estudantil repetindo a célebre frase: "mataram um estudante e poderia ser seu filho".

A situação era tensa e preocupava o secretário de segurança e o governador que sabiam a força dos estudantes e, principalmente, os reflexos da violência policial escancarada contra a sociedade. A situação se configurou de fato nos dias seguintes quando milhares de estudantes lotaram quase que diariamente as praças do centro da cidade para se manifestarem.

Na quinta feira, dia 03 de junho de 1968, os estudantes universitários, reunidos em assembleia geral, na Faculdade de Medicina, decidiram elaborar um documento de reivindicações e apresentá-lo ao reitor. Deliberaram também por uma passeata de protesto contra o corte de verbas e a crise na Universidade. O ato "pacífico" recebeu permissão do governo estadual, contou com apoio de padres, intelectuais, professores e da população. Aos gritos de "Abaixo o MEC-USAID", cerca de três mil estudantes se concentraram na Praça da Sé e de lá saíram pelas ruas, portando faixas e cartazes de protesto contra o governo, até o Campo Grande. No trajeto, picharam ônibus, carros, casas comerciais e prédios públicos com frases como: "viva a guerra popular" ou "abaixo a ditadura".

O trajeto inicial definido em assembleia previa que o fim dos protestos seria na Barroquinha, porém, era impossível controlar o sentimento de revolta e o desejo de mudança daqueles jovens. Decididos a demonstrarem sua força contra o arbítrio, cerca de cem manifestantes seguiram para as imediações da reitoria, atacaram o imóvel da Secretaria de Educação utilizado pela comissão executiva do convênio MEC-USAID na Bahia, incendiaram suas dependências, saquearam os arquivos e atiraram os papéis no lixo. Ao ouvirem gritos denunciando a chegada da polícia, os estudantes que ocupavam o prédio da Secretaria de Educação se dispersaram sem serem alcançados. 
Nesse dia, bancos e casas comerciais fecharam mais cedo, os carros oficiais deixaram de circular pelas ruas do centro cujo trânsito de pedestres e automóveis era raro. $\mathrm{O}$ fato teve larga repercussão nos espaços políticos e muitos manifestaram discreto apoio à causa estudantil, porém, intimidados com as constantes delações e perseguições fizeram inúmeras ressalvas.

Tamanha violência nas manifestações dos estudantes contra o acordo MEC-USAID fundamentava-se nos propósitos do convênio e em sua vinculação com a ditadura. Com a reorganização do Estado, após o golpe militar, a educação nacional em todos os níveis passou por profundas transformações, com a finalidade de adequá-la aos objetivos da quartelada de abril. $\mathrm{O}$ acordo do Ministério da Educação e Cultura contra uma agência americana denota claramente esses propósitos e, mais ainda, denunciava, com clareza, a concepção de educação que seria aplicada daí em diante: Os professores teriam que se alinhar, sob coerção, ao sistema educacional ideologicamente autoritário e capitalista, utilizando técnicas e livros didáticos produzidos, especificamente, com essa finalidade. A primeira providência foi afastar os descontentes "Os intelectuais comprometidos com a revolução, com o reformismo, ou mesmo com o liberalismo já não serviam, não eram confiáveis." (CUNHA \& GÓES, 1994, p. 32).

Os resultados para a educação seriam, portanto, avassaladores e os estudantes baianos sabiam disso, do mesmo modo que seus colegas de outras regiões do país. O desrespeito à liberdade intelectual dos professores e alunos motivou tamanha rebeldia dos estudantes.

Em junho de 1968, a Universidade, novamente, estava paralisada por uma greve apoiada pelos professores, motivada pelo corte de verbas e suas consequências para o ensino superior, que se iniciou em algumas faculdades e se estendeu a toda Universidade com ocupações por tempo indeterminado. Apesar das verbas suplementares conseguidas pela Reitoria junto ao governo federal, os estudantes não acreditavam que pudessem resolver a carência do ensino público na Bahia. Os discentes já conheciam a intenção do governo estadual de desmontar o ensino público, instituir as fundações e cobrar anuidades.

Reunidos em assembleia, cerca de três mil estudantes decidiram ratificar a decisão de greve tomada nas faculdades. É evidente, entretanto, que não havia homogeneidade ideológica nos meios estudantis, e muitos jovens militavam em organizações de direita combatendo os atos e as manifestações daqueles que se identificavam com as propostas socialistas ou mesmo progressistas. Um fato ocorrido na madrugada de uma quinta-feira, dia 14 de junho de 1968, exemplifica essa situação: um grupo de jovens mascarados, ocupando um automóvel, lançou uma bomba que atingiu o departamento cultural da Universidade Federal da Bahia. A explosão acordou a vizinhança e assustou pacientes e funcionários do Hospital das Clínicas. O atentado, atribuído à JERB (Juventude Estudantil Revolucionária Brasileira) um grupo formado por estudantes de extrema direita, foi visto por estudantes que ocupavam o prédio de uma faculdade próxima.

Na madrugada do dia de 21 de junho de 1968, duzentos policiais militares, civis e bombeiros invadiram com cães treinados as faculdades e colégios ocupados pelos estudantes e prenderam o material de greve. Na tarde do dia seguinte, a polícia atacou com cães e bombas de gás líderes estudantis reunidos em um ponto de ônibus na Ladeira da Conceição.

Mesmo diante da violenta repressão, os estudantes reunidos em assembleia decidiram continuar a greve contando com o apoio dos residentes de medicina que suspenderam o atendimento nos hospitais em represália à invasão da Faculdade.

Diante dos últimos acontecimentos e mediante exigência do governo federal, o Secretário de Educação Luís Navarro de Brito distribuiu nota oficial no dia 08 de julho de 
1968, proibindo as passeatas. Mesmo assim, os estudantes rebeldes se concentraram dias depois, em frente à Prefeitura Municipal, para protestar contra o aumento das passagens do transporte coletivo que havia sido decretado no dia anterior. Distribuíram milhares de panfletos pelas ruas, interromperam o tráfego e fizeram discursos de protesto.

Quatro dias depois, o movimento de rebeldia voltou às ruas para protestar contra a prisão, no Estado da Guanabara, do líder estudantil Vladimir Palmeira e novamente foi impedido pela guarda civil de se manifestar. João Jorge Amado, filho do famoso escritor baiano, que não participava do ato, foi espancado inexplicavelmente quando se dirigia à sede do jornal A Tarde em companhia de um amigo. Os estudantes, que já haviam recuado, investiram em massa sobre os policiais para resgatar o jovem e foram recebidos a tiros. Fugiram, então, pela Praça da Sé onde houve novo confronto com os policiais.

Tamanha era a violência que toda a parte central da cidade estava tomada por policiais civis, militares, guarda municipal, polícia federal e agentes do DOPS. Casualmente os manifestantes encontraram um aliado: do serviço de som do elevador Lacerda, o locutor conclamava o povo a se unir aos estudantes. Além do evidente desequilíbrio de forças havia uma tenacidade sanguinária nos órgãos de repressão civis e militares e ao primeiro sinal de que um policial havia se ferido, investiram ferozmente com metralhadoras em punho gritando: "agora vai haver sangue" e de baioneta calada, investiram indistintamente contra o povo desarmado nas imediações da Prefeitura Municipal e do Palácio Rio Branco.

Da mesma forma investiram contra o deputado federal José Penedo, o vereador Antônio Casaes e diversos jornalistas lançando bombas de gás e ameaçando-os com cães ferozes. Novamente o comércio e os bancos fecharam, as baianas abandonaram os tabuleiros e os estudantes marcaram novo ato para protestar contra a violência.

Repetindo em dose infinitamente superior à violência da manifestação anterior, a polícia investiu furiosamente contra os estudantes e populares nas ruas do centro da cidade, na quinta-feira, dia 08 de agosto de 1968. A cidade virou uma praça de guerra. Cerca de três mil estudantes se espalharam por diferentes pontos da cidade para protestar contra a violência. Nas imediações da Praça Castro Alves, os policiais começaram a atirar contra um grupo de estudantes e populares, que, com apoio do Abade Dom Timóteo Amoroso, que fora proibido por seus superiores eclesiásticos de participar da manifestação, se refugiaram no Mosteiro de São Bento, explicitando definitivamente a posição política da autoridade beneditina. (A TARDE, 09/08/1968, p. 01,02 e 03).

Um jovem católico progressista, vinculado a entidades juvenis de ação católica e amigo de D. Timóteo, narrou que nesse dia a repressão policial acuou muitos jovens na porta do Mosteiro. Em socorro aos estudantes

D. Timóteo e outro monge abre, cada um, uma porta. D. Timóteo fecha a porta. Os policiais militares arrombam, defrontam-se com o Abade, que lembra que o mosteiro, além de igreja, era domicílio e que não podia ser invadido sem mandado judicial. Enquanto o Abade recua lentamente, diante da horda, os jovens que fugiam já estão conseguindo sair pela porta dos fundos na Rua Paraíso (...) Ultrapassando a igreja os policiais chegam ao claustro (...) invadem o mosteiro, revistam as celas dos monges, encontrando cerca de vinte estudantes que são presos, e começam a apanhar ainda no mosteiro e na frente do Abade, que protesta. (...) Depois da saída dos militares, o Abade encontra mais ou menos a mesma quantidade de estudantes escondidos no mosteiro, assume a posição de hospedeiro e começa a providenciar alimentos e pouso para os estudantes. (...) Escoltado por policiais, o Abade se dirige, no começo da noite, à Secretaria de Segurança Pública para protestar contra o cerco e pela segurança dos presos. O secretário liga para o Governador e para o Comandante da $6 .^{\mathrm{a}}$ Região Militar. Consegue que um juiz de menores, acompanhado por D. Timóteo, tire e liberte 
os menores. D. Timóteo acompanhou e deu esperança aos maiores. (CARVALHO NETO, 1996, p.24)

Conquanto houvesse estudantes protegidos no mosteiro, outros tantos estavam nas ruas próximas em ativo combate contra a repressão, enquanto os policiais que ficaram fora do mosteiro se viram, de repente, desmuniciados aguardando reforço. Logo depois, o tiroteio recomeçou no meio dos carros que serviam de barricada aos grupos rivais. Alguns estudantes conseguiram entrar numa casa de materiais de construção e, municiados de seu estoque, forçaram um recuo policial. Os estudantes resolveram voltar à Praça da Sé uma vez que as ruas estavam vazias devido à mudança do sentido do tráfego, mas fugiram com a polícia em seu encalço. Os motoristas de ônibus posicionaram os coletivos na rua de forma a retardar e dificultar a ação repressiva, e os estudantes tivessem tempo de fazer comícios relâmpagos e se dispersarem.

No dia seguinte o governador admitiu na televisão o descontrole da situação e se dispôs a negociar com os estudantes. Essa atitude tem um sentido representativo muito forte porque traz a dimensão da força política que esses atos representavam contra um governo local que tinha o apoio dos militares e contava com um efetivo policial infinitamente superior ao número daqueles opositores rebeldes.

Além disso, as ações policiais deixaram indignada a sociedade baiana que viu seus filhos serem reprimidos com absurda violência numa luta onde o equilíbrio de forças era visivelmente desigual. $\mathrm{O}$ vespertino pesquisado admitiu suas diferenças ideológicas dos jovens rebeldes, mas julgou ser insensata a atitude das autoridades baianas e solicitou bom senso. Considerou os atos de protesto não uma iniciativa de uma minoria ínfima, mas um gesto de solidariedade do povo.

A dinâmica estudantil e a violência policial passaram a se refletir diretamente no cotidiano das pessoas e havia um ambiente de tensa expectativa na cidade. No dia 13 de agosto de 1968, as ruas da cidade estavam vazias, a população com medo mantinha as janelas fechadas, as lojas contabilizaram os prejuízos no dia dos pais, os estudantes continuavam tensos, a polícia nas ruas, consultórios médicos sem clientes, cinemas vazios, e ninguém saiu para comprar jornais.

A morte do Cardeal Dom Augusto Álvaro da Silva, arcebispo radical e ultraconservador, consternou a população católica e os estudantes, cautelosos, passaram a fazer as manifestações nos bairros, começando pela Liberdade, evitando assim, o centro da cidade. Em contrapartida, a polícia não deu trégua e, desconsiderando o luto católico, invadiu, mais uma vez, o Mosteiro de São Bento e obrigando os fiéis a desfilar sob a mira de suas armas. Essa prática constante visava o intimidamento de D. Timóteo, inabalável, na defesa dos oprimidos.

Passada a trégua, os estudantes voltaram a se concentrar no centro da cidade protestando contra a política educacional e o aumento das tarifas do transporte coletivo. Desde então, nova trégua seria dada para organizar e discutir a participação no fatídico Congresso Nacional dos Estudantes.

Na Faculdade de Direito, contudo, o entrevero duraria mais alguns dias. Uma parte dos estudantes de direito se recusou a permitir a presença no recinto escolar dos tenentes Átila Brandão e Francisco Pitanga, alunos que espancaram e prenderam manifestantes no mês anterior, gerando um clima de tensão na Faculdade. Os alunos indesejáveis, em companhia de outros policiais, decidiram entrar na sala de aula contra a vontade dos colegas e, para evitar conflitos, as aulas foram suspensas pela congregação. Os discentes entraram com uma representação na direção da Faculdade e levaram o caso ao reitor da Universidade. (A TARDE, 10/09/1968, p. 03) 
Depois de algumas providências, a Faculdade foi reaberta, e os militares, novamente vistos na escola, foram forçados a se retirar. $\mathrm{O}$ tumulto generalizado obrigou a congregação a suspender novamente as aulas por tempo indeterminado. O presidente do Centro Acadêmico Rui Barbosa, Rosalindo de Souza, que morreria quatro anos depois na Guerrilha do Araguaia, e demais estudantes do curso ocuparam todas as dependências da Faculdade em protesto contra seu fechamento. No dia 29, armaram barracas e acamparam em frente à Reitoria para exigir a conclusão do inquérito instaurado para apurar o caso. A Faculdade só foi reaberta dois meses depois.

Depois do recuo para organizar o congresso estudantil, os inquietos e rebeldes manifestantes se concentraram na Praça da Piedade como vinham anunciando há uma semana. Desta vez, para protestar contra a prisão de seus líderes que participaram do congresso da União Nacional dos Estudantes na cidade de Ibiúna. O comércio da Rua Chile fechou as portas, e a polícia se antecipou tomando todo o trajeto da Praça Castro Alves à Praça da Sé. Os líderes do movimento mudaram a estratégia e deslocaram-se para a zona comercial e financeira na cidade baixa. O confronto violento com a guarda municipal aconteceu na Praça da Inglaterra. Do alto dos prédios, os funcionários públicos atiravam objetos nos policiais que reprimiam a manifestação estudantil e invadiam bancos, correios e lojas para prender manifestantes.

Alguns populares aglomerados em pontos de ônibus se feriram ao se precipitarem através das portas de vidro ou foram alvejados com tiros, pela polícia, ao serem confundidos com manifestantes. Da confusão, saíram muitos estudantes feridos e presos para responder IPM's com base na Lei de Segurança Nacional.

No fim da última semana de outubro de 1968, chegaram a Salvador os estudantes universitários baianos presos no Congresso da UNE em Ibiúna, São Paulo, para serem ouvidos na Delegacia Federal de Segurança Pública, localizada na Vila Militar do Bonfim. As moças foram imediatamente liberadas e os rapazes, inclusive menores, mantidos presos, cinco deles, incomunicáveis.

\section{CONCLUSÃO}

Tantos fatos, exaustivamente narrados, merecem uma análise que nos remete aos objetivos desse estudo. Eles mostram a quantidade e a intensidade dos atos de rebeldia contra o regime militar na Bahia. Algumas dessas manifestações, que reuniram milhares de estudantes, tiveram profunda repercussão na sociedade local, quer pela relevância e coerência das demandas estudantis, quer pela violência com que foram reprimidas. Em muitos casos, as autoridades políticas baianas foram obrigadas a recuar, ainda que momentaneamente, da fúria repressiva ou mudar de estratégia por causa da opinião pública. De um modo geral, as manifestações estudantis serviram para alertar a população contra os desmandos autoritários na Bahia, que, por conta da censura, dificilmente chegariam ao conhecimento público, não fossem as denúncias explícitas dos estudantes. Ainda que isolados da maioria absoluta da população, os estudantes lograram romper a hegemonia pretendida pelos golpistas e seus aliados. 


\section{REFERÊNCIAS}

CARVALHO NETO, Joviniano Soares de. Theodomiro: Os limites da mídia e da anistia. A imprensa baiana e o primeiro condenado à morte na República. Salvador: Universidade Federal da Bahia, Agosto de 2001. (Dissertação de Mestrado)

CUNHA, L. A \& GÓES, M. de. O golpe na educação. 8. a ed. Rio de Janeiro: Jorge Zahar Editor, 1994.

OLIVEIRA JR. Frankilin. A usina dos sonhos: sindicalismo petroleiro na Bahia 1954 1964. Salvador: EGBA, 1996.

RAPOSO, Eduardo (coord.) 1964 - 30 anos depois. Rio de Janeiro: Agir, 1994.

REIS FILHO, Daniel Aarão. 1968, o curto ano de todos os desejos. Tempo Social, Revista Sociologia. USP, S. Paulo, 10 (2): 25-35, outubro de 1998.

REIS FILHO, Daniel Aarão. A revolução faltou ao encontro. São Paulo: Brasiliense, 1990.

REIS FILHO, Daniel. A., SÁ, J.F. de (Org.) Imagens da revolução. Rio de Janeiro: Marco Zero, 1985.

NADER, Ana Beatriz. Os autênticos do MDB: semeadores da democracia. História Oral de vida política. São Paulo: Paz e Terra, 1998.

SIRKIS, Alfredo. Os carbonários. 11ª . Ed., Rio de Janeiro: Record, 1998.

SOUZA. Sandra Regina Barbosa da Silva. Ousar lutar, ousar vencer: história da luta armada em Salvador. (1969 - 1971). EDUFBA, 2013.

VENTURA, Zuenir. 1968: O ano que não terminou: a aventura de uma geração. Rio de Janeiro: Nova Fronteira, 1988.

WEIS, Luiz. A palavra dos estudantes: eles querem construir. Revista Realidade. Ano IV, Número 42, p. 24-39, Setembro de 1969.

Notas

${ }^{1}$ Professor Adjunto do Departamento de História e pesquisador do Grupo de Estudos Política e Sociedade no Museu Pedagógico da Universidade Estadual do Sudoeste da Bahia (UESB). E-mail: jdiashistory@hotmail.com

${ }^{2}$ As mesas diretoras da Assembleia Legislativa do Estado e das Câmaras Municipais foram recompostas ao gosto dos comandantes militares. O prefeito de Salvador, Virgildásio Sena, eleito pela UDN em 1962, mas que alguns dias antes comparecera a um comício para manifestar apoio aos reformistas, foi afastado do cargo, denunciado em um inquérito de quatro volumes e, posteriormente, cassado. Além desse, foram cassados os prefeitos José Fernandes Pedral Sampaio, de Vitória da Conquista e o próprio Francisco Pinto, de Feira de Santana.

${ }^{3} \mathrm{Na}$ ocasião, vários estudantes e líderes sindicais ligados a entidades como o Sindicato da Indústria de Panificação, Associações Profissionais de Trabalhadores da Indústria de Construção Civil, Liga Patriótica dos Artistas e os demais empregados em estabelecimentos bancários e trabalhadores em artefatos de couro, foram presos. Varias prisões foram efetuadas no interior e, dentre os presos recolhidos aos quartéis militares e à Colônia Agrícola de Pedra Preta, vários eram originalmente de Alagoinhas, Aramari, Brumado, Cruz das Almas, Candeias, Conceição do Almeida, Feira de Santana, Jacobina, Ipirá, Irará, São Gonçalo dos Campos, Mata de São João, Iaçu, Jequié, Vitória da Conquista, Ilhéus, Várzea do Poço, 
Itabuna e Itapetinga. Normalmente, os presos eram encaminhados ao Quartel dos Aflitos para triagem e liberados em seguida.

4 No ano de 1968, por exemplo, o orçamento da União para Defesa e Segurança foi de Ncz\$ 1.700.000.000,00 (um bilhão e setecentos milhões de cruzeiros novos) e para Educação e Cultura Ncz\$ 800.000.000,00 (oitocentos milhões de cruzeiros novos).

${ }^{5}$ Trata-se da Lei Federal n. ${ }^{\circ} 4464$ de 09/09/1964, regulamentada pelo decreto 56241, de 04/05/1965.

${ }^{6}$ Carlos Sarno, em depoimento ao autor, em 2001.

${ }^{7}$ Carlos Sarno, em depoimento ao autor, em 2001.

${ }^{8}$ Carlos Sarno, em depoimento ao autor, em 2001.

9 O IPM para apurar o caso envolvendo o tenente-coronel João Mansur de Carvalho foi instalado pelo delegado Valter Lino Drummond, do Departamento Federal de Segurança Pública na Bahia.

Recebido em abril-2014

Aprovado em maio-2014 